\title{
Listening to Unreason: Foucault and Wittgenstein on Reason and the Unreasonable Man ${ }^{1}$
}

\author{
LIAT LAVI \\ Bezalel Academy for Arts and Design, Jerusalem; Bar Ilan University, Ramat Gan.
}

\begin{abstract}
In this paper I examine Wittgenstein's appeals to madness in On Certainty in light of Foucault's Histoire de la folie. A close look at these works, usually conceived as disparate, belonging to entirely different schools of thought, reveals they actually have much in common. Both can be read as investigations into the grounds of reason, and while they offer quite different and distinct perspectives on the matter, they share some central insights. In both we find that the boundaries of reason are not only vague but also largely founded upon the relations - social in Foucault, sociolinguistic in Wittgenstein - between the reasonable person and the unreasonable person. Both perspectives reveal a curious state of affairs whereby the reasonable person is the one who dominates discourse, and yet, in his claim for reason, remains forever dependent upon the unreasonable person and his rejection. The pressing question triggered by Foucault's account is whether the boundary between reason and unreason is at all necessary. This undermines Wittgenstein's thesis that this boundary is a matter of logical necessity upon which discourse depends. I flesh this point out in the paper also by examining the differences in Wittgenstein's and Foucault's treatments of Descartes' Meditations. I conclude that Wittgenstein's criticism of Cartesian skepticism presented in On Certainty loses much of its fortitude once examined in light of Foucault's Histoire de la folie.
\end{abstract}

Keywords: Foucault, Wittgenstein, Descartes, reason, the reasonable man / person, déraison, madness.

\footnotetext{
${ }^{1}$ Earlier versions of this paper were presented at the Hebrew University and Bar Ilan University International Conference, Foucault: The Mask Philosopher (2014) and at the Essex Graduate Philosophy Conference, Madness, Disorder, and Society (2016). I am grateful to Dror Yinon for his insightful comments on an earlier version of the paper that especially contributed to the writing of section 5.3 .
} 


\section{DIFFERENT APPROACHES, COMMON GROUNDS}

Both Foucault's Histoire de la folie and Wittgenstein's On Certainty can be read as investigations into the grounds of reason. ${ }^{2}$ The two offer quite different and distinct perspectives on the matter, and yet seem to share some central insights. In both we find that the boundaries of reason are not only vague but are also largely founded upon the relations, sociohistorical in Foucault, logical and linguistic in Wittgenstein, between the reasonable and the unreasonable person.

Both perspectives also reveal a curious state of affairs whereby the reasonable person is the one who dominates discourse, and yet, in his claim for reason, remains forever dependent upon the unreasonable person and his rejection. In a sense we could say that it is rather the reasonable that is negatively defined as the 'not unreasonable'. Both Foucault and Wittgenstein are also critical of the dichotomous conception of reason, and in both cases their views can be regarded as criticisms of Descartes' appeals to doubt (the criticism of Descartes is explicit in Foucault and implicit in Wittgenstein).

There are, however, crucial differences between Wittgenstein's and Foucault's projects that first and foremost pertain to the nature of the investigation, its form and method. When considering the boundary between reason and unreason (in Foucault, déraison), the two ask very different questions, which determine the course of the investigation that follows: Wittgenstein seems to ask where the boundary between reason and unreason is located and how it functions, while Foucault asks when it was formed and why it came to be.

As we shall see, while Wittgenstein regards the boundary between reason and unreason to be a logical necessity upon which language is founded, Foucault poses the apparently historical question of when the 'boundary' was formed. In Foucault's words:

We need to identify the moment of that expulsion, before it was definitely established in the reign of truth, before it was brought back to life by the lyricism of protestation. To try to recapture, in history, this degree zero of the history of madness, when it was undifferentiated experience, the still undivided experience of the division itself. To describe, from the origin of its curve, that 'other trick' which, on either side of its movement, allows Reason and Madness to fall away, like things henceforth foreign to each other, deaf to any exchange, almost dead to each other... The gesture that divides madness is the constitutive one, not the science that grows up in the calm that returns after the division has been made. ${ }^{3}$

We could write a history of limits - of those obscure gestures, necessarily forgotten as soon as they are accomplished - through which a culture rejects something which for it will be the Exterior. ${ }^{4}$

\footnotetext{
${ }^{2}$ Michel Foucault, Folie et déraison: Histoire de la folie à l'âge classique (1961), English trans. Jonathan Murphy and Jean Khalfa, History of Madness [1961] (2006) [Abb: Histoire de la folie]; Ludwig Wittgenstein, On certainty: material from the last year and a half of Wittgenstein's life (1949-51), eds. G.E.M. Anscombe and G.H. von Wright, trans. G.E.M. Anscombe and Denis Paul (1969) [Abb: OC]. Emphases in the quotes from OC are mine.

${ }^{3}$ Histoire de la folie, xxvii-xxviii, included in the preface to the 1961 edition.

${ }^{4}$ Ibid., xxix.
} 
Posing the question of when the boundary between reason and unreason was drawn carries with it the even more pressing question of whether the boundary is at all necessary, and whether we can conceive a world of discourse largely lacking it. For Wittgenstein the use of language logically necessitates that such a boundary is set in place, if only implicitly. Thus, questions of the type put forward by Foucault simply could not occur in Wittgenstein. Of the latter question, namely whether a discourse lacking this boundary could exist, Wittgenstein seems to answer in the negative. In sections 2 and 3 I present and discuss Wittgenstein's account in greater detail.

The accounts presented by Wittgenstein and Foucault also differ in their treatment of Descartes. Unsurprisingly, for Foucault Descartes is an actual person who lived at a certain historical period and who reacts to and reflects the societal norms of his time. Wittgenstein makes no direct appeal to Descartes, ${ }^{5}$ but it seems quite straightforward that the 'general skeptic' he envisions takes much after Descartes. ${ }^{6}$ Unlike Foucault, however, Wittgenstein does not deal with Descartes the person, but with a 'Cartesian typecast' (and possibly, a 'Cartesian straw-man', see section 5.2). Foucault, moreover, engages in a careful reading of Descartes, and analyses the different types/mechanisms of doubt presented in Descartes' Meditations (discussed in section 4). His careful analysis is not only insightful in its own right, but turns out to jeopardize, or at least significantly weaken Wittgenstein's critique of the (Cartesian) general skeptic. Section 5 offers a critical reading of OC in light of Foucault's analysis of Descartes' Meditations.

\section{THE IMPLICATIONS OF RAISING UNREASONABLE DOUBTS}

On Certainty can be seen as a continuation of Wittgenstein's previous investigations in arguing that language is inseparable from praxis and draws from very intricate background knowledge, which for the most part remains implicit. Similarly to the line of thought presented by Wittgenstein in Philosophical Investigations, we find in OC that while we cannot point to the boundaries or limits of language, we keep running up against them. ${ }^{7}$ OC deals specifically with the question of knowledge and certainty, and one of the boundaries it exposes by means of running up against it, is that between reason and unreason.

OC opens with a discussion of Moore's proof of the existence of external reality. Moore's proof is focused on outlining the conditions for holding a proof valid, or 'rigorous', to use his own words, but it builds on the contention that his premises do not require

\footnotetext{
${ }^{5}$ Andy Hamilton suggests Wittgenstein's lack of reference to "the accepted Western canon from Descartes to Kant" is meant "to enhance the appearance of his own originality", Andy Hamilton, Wittgenstein and On Certainty [Routledge Guidebook] (2014), 18.

${ }^{6}$ As Hamilton notes, "Wittgenstein rarely cites philosophers in the Western canon. Despite this, On Certainty clearly targets Descartes' dream-scepticism, and Kenny is not mistaken when he describes it as conducting "a three-cornered argument with Moore and the Cartesian sceptic" (Ibid.,155). Annalisa Coliva offers an interesting account of On Certainty that 'splits' the skeptical positions it addresses to Cartesian and Humean views. See Annalisa Coliva, Moore and Wittgenstein, Skepticism, Certainty and Common Sense (2010), esp. Ch. 3, pp. 103-4.

${ }^{7}$ See Ludwig Wittgenstein, Philosophical Investigations, trans. G.E.M. Anscombe [1953] (1958) [Abb: PI], §119: “The results of philosophy are the uncovering of one or other piece of plain nonsense and the bumps that the understanding has got by running its head against the limits of language. These bugs make us see the value of the discovery".
} 
proof in themselves. The premise Moore's proof builds on consists of his waving his hands in the face of his interlocutor and insisting that they are there. ${ }^{8}$ When the interlocutor challenges Moore's certainty of the existence of his hands, Moore simply goes on insisting that they are there and that he knows so. His premises, namely "Here is one hand, and here is another", ${ }^{9}$ Moore insists, do not require proof in themselves. And Moore states explicitly: "I can know things, which I cannot prove". ${ }^{10}$ Moore thus argues that certain knowledge is evidential, and considers objections to this stance as "wrong". ${ }^{11}$ Wittgenstein follows Moore in rejecting the skeptical stance, but suggests that Moore's interlocutor's reply is not wrong, but rather makes no sense. ${ }^{12}$

Making sense is the core issue for Wittgenstein - expressing certain doubts, he shows, takes the sense away from words such as 'knowledge,' 'certainty' and 'doubt' (or 'hand' see OC \$268). If we question Moore's knowledge of the existence of his own hands, we (the skeptics) are misusing the word 'know'. If we ask him how he could be certain of its existence, we are misusing the word 'certainty'; we are negligent of its sense, or of how this word came to have a sense in the first place. For Wittgenstein, the point is not that knowledge of the type Moore refers to is 'evidential', but rather that this kind of knowledge is the background upon which the sense and meaning of the above mentioned words are constituted.

Wittgenstein goes on to claim that positive utterances of the form "I am certain that my hand is here", or "I know that this is my hand" are also nonsensical, for they implicitly suggest that the contrary is sensible, i.e., that I could be uncertain that this is my hand. This is so, although in certain - quite rare cases - doubt in the fact of the matter could be justified and utterances such as "I know this is my hand", or "I'm not sure this is my hand", could make sense. Such are cases when, for example, my hand is put in cast, and I am unsure as to whether I underwent an arm transplant. The possibility of such utterances having sense in unusual cases, Wittgenstein argues, make us oblivious of the fact that our general use of 'know' and 'certainty' builds on the fact that in normal circumstances such utterances are nonsensical. Here, Wittgenstein's claim is made against Moore. When Moore replies to the skeptic 'I know this is my hand,' he too is expressing a nonsensical utterance, and is in fact misusing the word 'know.'

Wittgenstein argues further that not only belief, but also doubt requires justification, or in his words, "grounds": 13

\footnotetext{
${ }^{8}$ Moore's paper, note, makes this claim after some 17 pages of a meticulous conceptual analysis of what is meant by 'external', 'existing outside us', 'having extension', 'being met with waving' proof that has received most of the attention, and this is largely true also in the case of Wittgenstein's treatment of Moore. See G. E. Moore, "Proof of an External World" [1939], reprinted in G.E. Moore, Selected Writings, ed. Thomas Baldwin [1993] (2013), 147-170.

${ }^{9}$ Ibid., 166.

${ }^{10}$ Ibid., 170 .

${ }^{11}$ Ibid.

${ }^{12}$ Notice that in PI $\S 119$ (quoted in fn. 8 above) Wittgenstein portrays the uncovering of nonsense as a (possibly, 'the') philosophical goal, and specifically relates this task to noting the effects of running up against the limits of language.

${ }^{13}$ Somewhat in the spirit of American Pragmatism. See OC $\$ 422$.
} 
122. Doesn't one need grounds for doubt?:14

322. What if the pupil refused to believe that this mountain had been there beyond human memory? We should say that he had no grounds for this suspicion;

This requirement, that a certain doubt raised would have grounds, is also expressed as a requirement for reasonability. This, note, shifts the discussion from utterances to utterers, i.e., to the characteristics of linguistic agents:

323. So rational [vernünftiges ] suspicion must have grounds? We might also say: "the reasonable man [Der Vernünftige] believes this.

According to Hamilton, Wittgenstein considers the skeptical arguments from madness or dream to be "self-defeating" as "it is a condition of such utterances [as 'Maybe I am mad' - L.L.] having meaning that what is said is false". ${ }^{15}$ That is to say, it is not that the utterance is nonsensical in itself, it is rather that if expressed, it implies that the utterer is not in a position to express the judgement they are thereby attempting to express. ${ }^{16}$

This is a crucial point. Wittgenstein does not simply deem certain doubts unreasonable or groundless; rather he equates 'making unreasonable utterances' with 'being an unreasonable person. This is a nontrivial move which occurs repeatedly in OC. In Wittgenstein's descriptions of being faced with doubts he considers 'unreasonable', the utterance immediately projects on our judgement of the person making it.

219. There cannot be any doubt about it for me as a reasonable person [vernünftigen Menschen]. - That's it. -

220. The reasonable man [Der vernünftige Mensch] does not have certain doubts.

257. If someone said to me that he doubted whether he had a body I should take him to be a half-wit [Halbnarren]. But I shouldn't know what it would mean to try to convince him that he had one. And if I had said something, and that had removed his doubt, I should not know how or why.

Equating 'raising unreasonable doubts' with 'being unreasonable' is problematic in itself. Even more problematic, however, is equating 'being unreasonable' with 'being insane', and yet, throughout the text we find that Wittgenstein largely conflates unreasonableness in general and 'insanity' or 'mental disturbance'. Both are used as the alternative to posing a grounded or reasonable doubt, or of making a reasonable mistake:

71. If my friend were to imagine one day that he had been living for a long time past in such and such a place, etc. etc., I should not call this a mistake, but rather a mental disturbance [Geistesstörung], perhaps a transient one;

72. Not every false belief of this sort is a mistake.

\footnotetext{
${ }^{14}$ All emphases in bold are mine.

${ }^{15}$ Hamilton, Wittgenstein and On Certainty, 236.

16 See Ibid.
} 
73. But what is the difference between mistake and mental disturbance

[Geistesstörung]? Or what is the difference between my treating it as a mistake and my treating it as mental disturbance [Geistesstörung]?

74. Can we say: a mistake doesn't only have a cause, it also has a ground? I. e., roughly: when someone makes a mistake, this can be fitted into what he knows aright.

155. In certain circumstances a man cannot make a mistake. ("Can" is here used logically, and the proposition does not mean that a man cannot say anything false in those circumstances.) If Moore were to pronounce the opposite of those propositions which he declares certain, we should not just not share his opinion: we should regard him as demented [Geistesgestört].

In fact, we can note in OC three versions of the thesis that are not identical: 1 . Unreasonable doubts are identified as doubts that a reasonable person would not have [e.g., §323, $219,220] ; 2$. A person raising such doubts should be regarded as an 'unreasonable person' [e.g., 257]; 3. A person uttering such doubts is insane, and should be treated as such [e.g., $71,73,155]$. The latter contention is the most troubling, and we will look into it further in the following section. It is troubling because Wittgenstein's account targets unreasonable doubts raised by philosophers, and it seems unreasonable to suspect Wittgenstein suggests they are insane.

Troubling as this argument may be, we should not rush to dismiss it. Wittgenstein, after all, is a philosopher of language, and it seems just to take his own use of words seriously. Wittgenstein could easily suffice with saying the utterances in question are 'vacuous, 'make no sense' or are 'meaningless', and could likewise insist that whoever utters them is negligent of their meaninglessness. He could further insist that such nonsensical usage of words is a 'philosophical malady ${ }^{17}$ that requires 'philosophical therapy'. ${ }^{18}$ By no means was he obliged to suggest that whoever makes such a claim should be regarded insane. Yet he does.

As always in Wittgenstein, language reflects praxis, and meanings of words refer back to underlying background knowledge assumed in praxis. ${ }^{19}$ In this specific case, however, the meaning of ' $\mathrm{know}^{\prime}$ and 'certainty' does not simply stem from our taking certain things to be evidently known, it stems from the praxis of treating the community of speakers as divided into reasonable and unreasonable persons, and more importantly for the present discussion, as divided into sane and insane persons. In drawing the picture of this praxis, of how the community of speakers acts, Wittgenstein is also assuming that once one is identified as 'unreasonable' or 'insane', discourse immediately stops (as implied, for example, by $\S 219, \S 257$ quoted above). I shall return to discuss this point in section 4.3 .

\footnotetext{
17 Or "Philosophical Disease", see PI §593.

18 Or "Philosophical Treatment", see PI §254. Also see PI §255: “The philosopher's treatment of a question is like the treatment of an illness." Also see PI §133: "There is not a philosophical method, though there are indeed methods, like different therapies."

${ }^{19}$ This issue has been extensively discussed in the literature. See, for example, G.P. Baker, and P.M.S. Hacker, Wittgenstein: Rules, Grammar and Necessity, vol. 2 (2009).
} 


\section{IS DESCARTES MAD?}

While, as noted, OC does not include a direct reference to Descartes, it appears quite plausible to identify Wittgenstein's skeptic interlocutor with Descartes. The challenge to Descartes' enterprise seems obvious - Wittgenstein shows that doubt itself requires justification. Moreover, following the above analysis it would seem that if Descartes raises unreasonable doubts, this would imply he is himself an unreasonable person, or possibly, even insane. $^{20}$

Wittgenstein does not seriously suggest that Descartes is mad, but does he suggest that the philosopher belongs in a separate language game in which doubting is founded on a more liberal practice ${ }^{21}$ This might be implied by the comparison Wittgenstein makes in §§ 467,468:

467. I am sitting with a philosopher in the garden; he says again and again "I know that that's a tree", pointing to a tree that is near us. Someone else arrives and hears this, and I tell him: "This fellow isn't insane [verrückt]. We are only doing philosophy."

468. Someone says irrelevantly "That's a tree" ... And now I ask him "How did you mean that?" and he replies "It was a piece of information directed at you". Shouldn't I be at liberty to assume that he doesn't know what he is saying, if he is insane [verrückt] enough to want to give me this information?

The exact same utterance, "That's a tree", appears here in two different contexts. In $\S 468$ it is uttered by 'someone' who aims at communicating a piece of information and in $\S 467$ it is uttered by a philosopher. Crucially, the response to this utterance dramatically changes with the change of context - the interlocutor of $\S 468$ is deemed "insane", but the philosopher of $\S 467$ is not.

Clearly the forgiveness with which the philosopher's utterance is treated reflects a difference in praxis. ${ }^{22}$ In the context of philosophy, raising unreasonable doubts does not culminate in deeming the utterer insane. We already noted that Wittgenstein considers praxis as constitutive of 'language games', so could it be that Wittgenstein suggests here that the philosopher belongs in a different language game in which 'knowledge', 'certainty' and so on have different meanings? This could by no means be the case, because this would debunk Wittgenstein's argument against the skeptic. If the philosopher had access to some other source from which his words drew their meanings, the analysis of the "non-philosophical" world of praxis and language could not serve to undermine it.

\footnotetext{
${ }^{20}$ Hamilton also considers this possibility, asking: "Is [Wittgenstein] really saying that doing philosophy has something insane about it?" (Wittgenstein and On Certainty, 59). Hamilton poses this question in analyzing $\S 467$ discussed below, and he concludes Wittgenstein is here using irony, which reflects, on Hamilton's account, Wittgenstein's "conflicted view of philosophy" (Ibid.). In what follows I put forward an alternative interpretation.

${ }^{21}$ I wish to thank the journal's editor for insightful comments on this point, which led to a substantial revision of the analysis put forth.

${ }^{22}$ For a reading of OC that focuses on separating the philosophical from the non-philosophical standpoint, see: Graciela De Pierris, "Philosophical Scepticism in Wittgenstein's On Certainty", in Scepticism in the History of Philosophy, ed. Richard H. Popkin (1996), 181-196.
} 
Descartes is not insane, he's "only doing philosophy". But this does not imply that his use of language bears sense. This is Wittgenstein's critique of the skeptic. The skeptic's doubts remain nonsensical on logical accounts, i.e., the hypothesized language game aimed at accommodating a general form of doubt is itself implausible, unreasonable:

115. If you tried to doubt everything you would not get as far as doubting anything. The game of doubting itself presupposes certainty.

124. I want to say: We use judgments as principles of judgment.

156. In order to make a mistake, a man must already judge in conformity with mankind.

In my own words, for the philosopher too, doubting requires a pre-established agreement on the meaning of 'certainty', and such agreement can only draw from praxis. Once the skeptic poses a general doubt, he loses ground of how the words he himself is using function.

Note that in $\S 71$ and the paragraphs that follow (quoted above), the interlocutor whose sanity is being doubted is a friend. In $\$ 155$ (quoted above), however, the person whose sanity could be doubted is Moore, a philosopher. Still, Wittgenstein says: “155. [...] If Moore were to pronounce the opposite of those propositions which he declares certain, we should not just not share his opinion: we should regard him as demented [Geistesgestört]". The scenario depicted in this passage, whereby Moore would deny his knowledge instead of affirming it, is entirely parallel to Descartes' position in the Meditations. This again indicates that there cannot be a 'philosophical language game' hermetically separated from the non-philosophical language game. On a liberal reading of §155 we could say that if Wittgenstein is not suggesting Descartes is mad, he at least suggests Descartes should be treated as such, i.e., that we could exempt ourselves from continuing to converse with him.

There is a second interpretation to $§ 155$, when applied to Descartes' case. It is possible that Wittgenstein is noting here that Descartes' account is deceitful. Let me explain. When Descartes says he doubts the existence of his own body, he could not possibly mean it. If he truly doubted this fact, it should come with an entire phenomenology that is nowhere present in his account, and that would in fact make his account impossible. If one seriously doubted the existence of one's own body, one would not be able to keep calm, philosophize, hold a piece of paper to write on, and so on. This doubt, in short, would not, and could not come in isolation. If it was not an expression of insanity, it would nevertheless, if genuine, lead to insanity. Thus, when Descartes calmly and logically proceeds in his investigation after expressing this doubt, we may assume that he is deceptive, that he doesn't truly doubt the existence of his own body. 


\section{FOLIE ET DÉRAISON ${ }^{23}$}

Let us now turn to Foucault's Histoire de la folie. Foucault's main argument in the book is that the line separating reason and unreason ('raison' and 'déraison') is by no means a given necessity, but rather a cultural and political construct ${ }^{24}$ that can be historically located around the $17^{\text {th }}$ century.

It is important to note that Foucault does not suggest that the notions of reason, unreason and madness first appeared in this period, but rather that prior to this period the notions of reason and unreason were not conceived as mutually exclusive, a binary dichotomy. Foucault considers the split between reason and unreason a contingent event, and refers to it as the "act of separation" (xxxii), or even as a "decision". ${ }^{25}$ As Roy Boyne notes, "Foucault implies that things, given different historical antecedents, could have been otherwise. His book on madness is haunted by this 'otherwise', by this alternative condemned to silence by history." 26

Foucault locates this "moment of ...expulsion... that 'other trick' which, on either side of its movement, allows Reason and Madness to fall away, like things henceforth foreign to each other..." (xxvii) between Montaigne and Descartes, writing:

Between Montaigne and Descartes an event has taken place which concerns the advent of a ratio. But the advent of a ratio in the Western world meant far more than the appearance of a 'rationalism'. More secretly, but in equal measure, it also meant the movement whereby Unreason was driven underground, to disappear, indeed, but also take root. $^{27}$

Foucault finds in Descartes Meditations and specifically in Descartes' treatment of madness an important manifestation of the emergence of the boundary between reason and madness. An often neglected fact, highlighted by Foucault, is that Descartes brushes over madness, and does not contend with it. Descartes is willing to entertain all forms of doubt, but stops when it comes to doubts raised by the madman, writing:

How could I deny that I possess these hands and this body, and withal escape being classed with persons in a state of insanity, whose brains are so disordered and clouded by dark bilious vapors as to cause them pertinaciously to assert that they are monarchs when they are in the greatest poverty; or clothed [in gold] and purple when destitute of any covering; or that their head is made of clay, their body of glass, or that they are

\footnotetext{
${ }^{23}$ In the context of the present discussion I will not dwell into the exact nature of the relationship between Folie (madness) and déraison (unreason), since our focus is their treatment as synonymous. For a more elaborate commentary on their relationship and how they figured in the titles of the different versions of the book, see Hacking, 2006. Hacking compares the book's title to Alice's Cheshire Cat and beautifully notes that "Madness is the visible grin, unreason the cat that has faded away" (Ibid., xii).

${ }^{24}$ Gutting terms it "a variable social construct", in Gary Gutting, "Foucault and the History of Madness", in The Cambridge Companion to Foucault, $2^{\text {nd }}$ edition, ed. Gary Gutting (2005), 47-70, on p. 50.

25 "that decision that both bound and separated reason and madness" (Histoire de la folie, xxxiii).

26 Roy Boyne, Foucault and Derrida: The Other Side of Reason (1990), 53.

${ }_{27}$ Histoire de la folie, 47.
} 
gourds? I should certainly be not less insane than they, were I to regulate my procedure according to examples so extravagant. ${ }^{28}$

Descartes, though well aware of the scope of doubts that could be introduced by doubting his own sanity, refuses to include it in his project of preemptive skepticism. He further adds that entertaining this type of doubt would in fact deem him insane ("I should certainly be not less insane than they, were I to regulate my procedure according to examples so extravagant"). In Foucault's words, "Madness is excluded by the subject who doubts, in order that he may qualify himself as a doubting subject" (more on this point below). ${ }^{29}$

This indicates, according to Foucault, that by the time of the Meditations, the exclusion of madness had already been completed. The boundary had already been formed. He writes:

The path taken by Cartesian doubt seems to indicate that by the seventeenth century the danger has been excluded, and that madness is no longer a peril lurking in the domain where the thinking subject holds rights over truth: and for classical thought, that domain is the domain of reason itself. Madness has been banished.

While man can still go mad, thought, as the sovereign exercise carried out by a subject seeking the truth, can no longer be devoid of reason. A new dividing line has appeared, rendering that experience so familiar to the Renaissance - unreasonable Reason, or reasoned Unreason - impossible. ${ }^{30}$

While other forms of error and illusion encircled the region of certainty, and at the same time liberated a certain form of truth, madness was excluded without a trace, leaving not even a scar on the surface of thought. Madness was simply of no use in the process of doubt's movement towards truth... Madness can be brushed aside on the path of doubt, as doubt, in so far as it is methodical, is wrapped in the will to stay awake, which at every instant is a refusal of the temptations that madness offers. ... Well before the Cogito, there is an archaic implication of the will and of the choice between reason and unreason. ${ }^{31}$

In response to Derrida's critique of his book, ${ }^{32}$ focusing specifically on Foucault's analysis of Descartes' treatment of madness in the Meditations, Foucault further explicates that

\footnotetext{
${ }^{28} 1$ st meditation. The English Trans. brought here is by John Veitch [1901], reprinted in René Descartes, Discourse on the Method and the Meditations (2008), on p. 74. Also note the expressive tone given to the latter sentence in the 1647 French translation: "Mais quoi? ce sont des fous, et je ne serais pas moins extravagant, si je me réglais sur leurs exemples $»$.

${ }^{29}$ Histoire de la folie, 561.

${ }^{30}$ Ibid., 46-47. ["Une ligne de partage est tracée qui va bientôt rendre impossible l'expérience si familière à la Renaissance d'une Raison déraisonnable, d'une raisonnable Déraison."]

${ }^{31}$ Ibid., 138-9.

${ }^{32}$ See Jacque Derrida, "Cogito and the History of Madness" in Jacque Derrida, Writing and Difference [1967] (2001), Ch. 2, 36-76. The fascinating debate between Derrida and Foucault on this point exceeds the scope of the present paper. For a thorough and insightful discussion of this debate, see Ch. 3 of Boyne, Foucault and Derrida: The Other Side of Reason. Also see Pierre Macherey, "The Foucault-Derrida Debate on the Argument Concerning Madness and Dreams", in Foucault/Derrida: Fifty Years Later, eds. Olivia Custer, Penelope Deutscher and Samir Haddad (2016), 3-20.

We should note, however, that Derrida can be seen as siding with Wittgenstein on this issue. His central criticism being that regardless of its ambition to describe "silence" and its awareness of its own problematics, Foucault's project remains self-defeating because it is conducted in language and thus cannot escape the order of reason dominating language. History, archelogy and language itself, on Derrida's argument, all assume the order of reason, and thus cannot break
} 
the reason madness was 'evaded' by Descartes is that it could not be followed without putting his entire enterprise at risk on juristic grounds. ${ }^{33}$ For Descartes, the line between reason and unreason is already set, and entertaining the doubts of the insane would imply he has himself crossed this line. Descartes had already internalized the boundary, and thus it is clear to him that doubts of the sort brought about by madness implicate directly on whomever raises them, excluding him from the possibility of conducting an investigation that rests entirely on the power of reason. Foucault reads Descartes as saying:

Can I doubt my own body, can I doubt my own actuality? The example of the mad, the insani, invites me to do so. But comparing myself to them, doing as they do, implies that I too will become like them, demented, incapable and disqualified from my meditative enterprise... madness is excluded by the subject who doubts, in order that he may qualify himself as a doubting subject. ${ }^{34}$

Descartes' aim in the Meditations is not simply to doubt, but to reconstitute the possibility of knowledge on the grounds of reason. Entertaining doubts that would identify him as insane, i.e., lacking reason, would prevent him from getting out of the skeptical situation he put himself into. The judgement 'Cogito ergo sum' would lose its fortitude entirely, were it uttered by an insane person. No judgement made by an insane person could be used as a lever to get him out of the skeptic muddle. ${ }^{35}$

The point made by Foucault is that despite the immense challenge to Descartes' project posed by the insane, Descartes feels comfortable simply brushing it off and continuing his investigation. For him to be able to do so, the exclusion of insanity must have been so powerful that madness would no longer seem as a threat to reason. The exclusion is not of insanity, but of the 'insane', society had already been divided into them (the insane) and us (the reasonable men). ${ }^{36}$ As it turns out from Foucault's analysis, the rejection of the madman, his exclusion, is crucial for the very possibility of resurrecting reason in face of the skeptical challenge. Thus, before reason could be grounded on the 'Cogito ergo sum', it must be grounded on the rejection of the madman. As paradoxical as it may sound, the unreasonable (person, doubt) must first be identified and excluded, in order for reason to appear.

\footnotetext{
outside it. He writes: "if Foucault's book, despite all the acknowledged impossibilities and difficulties, was capable of being written, we have the right to ask what, in the last resort, supports this language without recourse or support: who enunciates the possibility of nonrecourse?" (Derrida, "Cogito and the History of Madness", 44-5); "The unsurpassable, unique, and imperial grandeur of the order of reason, that which makes it not just another actual order or structure (a determined historical structure, one structure among other possible ones), is that one cannot speak out against it except by being for it, that one can protest it only from within it" (Ibid., 42).

${ }^{33}$ Histoire de la folie, appendix II, "My Body, This Paper, This Fire” [« Mon corps, ce papier, ce feu » 1972].

${ }^{34}$ Ibid., 560-1.

${ }^{35}$ Note that on this reading the madman also poses a theological threat.

${ }^{36}$ Foucault also points to an underlying ethical conception of madness: that it could be overcome by willpower. See more on this in section 5.3.
} 


\section{REREADING ON CERTAINTY IN LIGHT OF FOUCAULT'S ANALYSIS}

\subsection{When Logic is Confronted with History}

In reading OC, the immediate impression is that Wittgenstein has succeeded in overcoming, or rather, chasing away, the skeptical challenge. His reply to the general skeptic is profound: the words used in the process of doubting draw their meaning from praxis, and the praxis they draw from is that of adhering to some familiar facts as 'certain beyond reasonable doubt'.

But to show this, Wittgenstein must run his head against the limits of language - it is not enough that he showed we assert with confidence certain facts, he must show that discourse would end if we doubted them. His reference to the madman is thus far from anecdotal, it is in fact necessary. It is by deeming certain doubts unreasonable that reason gets its meaning. It is only by rejecting the madman that intersubjective agreement in a given community can be established.

In Wittgenstein's picture, the line drawn between reason and unreason is a necessary condition for the possibility of language. Wittgenstein recognizes that this line is dynamic and historically dependent, ${ }^{37}$,i.e., that its 'location' changes with time and in different cultures, but this does not change the fact that the entire argument builds on the existence of this line, and on the praxis of the exclusion of the madman.

If, however, Foucault is correct in asserting that this line is not necessary but is rather a historical fact, that the praxis of excluding the madman can be dated, and that a world lacking this praxis not only could exist, but indeed existed, OC seems to lose much of its power.

One could object that in a world where the limit is not set, and the praxis of excluding the madman is not yet formed, the meaning of 'knowing' and 'certainty' would be entirely different. It is not that language would cease to exist or lose its grounds, it is simply that certain words would function differently, and other practices would establish their meaning. Wittgenstein, on such a view, is himself a flesh and blood person who lived at a certain historical period, and could do nothing other than describe the practices of his own time. It is not that in a different world, lacking the boundary between the reasonable men and the madmen, there would be no logical necessity determining the meaning of ' $k$ now', it is simply that this logical necessity would need a different source to draw from.

This seems a plausible objection. It may be that OC does not lose its power entirely once its logical premise is historicized. But OC certainly does not look as powerful as it did before.

Let us consider another issue in OC that comes to the fore when reading it in light of Foucault's Histoire de la folie.

\footnotetext{
${ }^{37}$ See, for example: OC $\S 65$. "When language-games change, then there is a change in concepts, and with the concepts the meanings of words change"; $\S 256$. "On the other hand a language-game does change with time"; $\$ 336$. "But what men consider reasonable or unreasonable [vernünftig oder unvernünftig] alters. At certain periods men find reasonable [vernünftig] what at other periods they found unreasonable [unvernünftig]. And vice-versa. But is there no objective character here? Very intelligent and well-educated people believe in the story of creation in the Bible, while others hold it as proven false, and the grounds of the latter are well known to the former".
} 


\subsection{A Cartesian Straw-Man}

Foucault's close reading of Descartes, highlighting Descartes' treatment of doubt raised by insane people, also reveals that Wittgenstein's 'Cartesian general skeptic' is a strawman. ${ }^{38}$ Descartes does not need Wittgenstein to know certain doubts are simply out of the question. Descartes, moreover, does not need Wittgenstein to know that the grounding of reason requires that we first exclude the unreasonable. If he is not saying so explicitly, he is nevertheless practicing this realization. Wittgenstein's 'Cartesian general skeptic' then does not take much after Descartes after all.

\subsection{Silence and Violence}

In the midst of a peaceful conversation, one tells her interlocutor he is insane, and walks away. This doesn't just end this specific conversation. From now on they are not on speaking terms, at least not until he withdraws from some position he expressed. Until he does, he is cast away from the community of speakers. When he speaks, he is told he is making no sense, and people walk away. In a community of speakers, this is a very violent act.

According to Foucault, the shift from the Renaissance to the modern period marks a shift in the approach to insanity. Insanity in the renaissance had to do with ethics, it signified a failure of a subject to overcome certain internal forces, a failure to adequately exercise their will power. In the modern period insanity loses this ethical dimension and becomes conceived as a natural phenomenon, an illness that is a matter for doctors. As madness is no longer regarded an ethical issue, a sin, but rather an illness, once it is not conceived judgmentally, we could suppose that power was replaced by mercy. This is not the case. Foucault assists us in recognizing the violence involved in the modern tactics of exclusion, in realizing these remain forms of executing power and sovereignty. The reasonable woman is defined, in fact constituted, through her rejection and exclusion of the madman. She shows no particular interest in the madman's fortune. She suffices herself with expelling the madman out of her hearing range, confining him to silence.

This 'rapture in dialogue', failure to communicate, is, according to Foucault, characteristic of the modern approach to insanity:

In the midst of the serene world of mental illness, modern man no longer communicates with the madman: on the one hand is the man of reason, who delegates madness to the doctor, thereby authorizing no relation other than through the abstract universality of illness; and on the other is the man of madness, who only communicates with the other through the intermediary of a reason that is no less abstract, which is order, physical and moral constraint, the anonymous pressure of the group, the demand for conformity. There is no common language: or rather, it no longer exists; the constitution of madness as mental illness, at the end of the eighteenth century, bears witness to a rupture in a dialogue, gives the separation as already enacted, and expels from the memory all those imperfect words, of no fixed syntax, spoken falteringly, in which the exchange between madness and reason was carried out. The language of psychiatry,

\footnotetext{
38 As in the previous discussion, I am here joining Hamilton and others in suggesting that Wittgenstein's general skeptic of OC takes much after Descartes; cf. fn. 6 above.
} 
which is a monologue by reason about madness, could only have come into existence in such a silence. ${ }^{39}$

Interestingly, Wittgenstein himself seemed to have been aware that taking a 'common sense' attitude towards the 'mentally ill' is offensive. He writes:

You must always be puzzled by mental illness. The thing I would dread most, if I became mentally ill, would be your adopting a common sense attitude; that you could take it for granted that I was deluded. ${ }^{40}$

I do not wish to go much into Wittgenstein's biography, but I would like to point to a certain tension in Wittgenstein's approach to the madman as it appears in OC. When looking into his biography, one finds insanity was a living threat for Wittgenstein. "I am often afraid of madness", ${ }^{41}$ he wrote. Louis Sass notes: ${ }^{42}$

"I often believe that I am on the straight road to insanity," Wittgenstein told a friend in 1948 (M 523). A diary entry from 1937 conveys his persistent sense of being on the brink: "I feel as if my intellect was in a very labile equilibrium; so as if a comparatively minor jolt could bring it to snap over. It is like when one sometimes feels close to crying, feels the approaching crying fit. One should then try to breathe quite calmly, regularly and deeply until the fit dissipates. And if God wills I will succeed" (D 159, 31.1.37). ${ }^{43}$

We noted earlier, in examining OC $\S 467$, that to an external observer, philosophizing may be easily confused with insanity by the community he lives in. This could certainly be said of Wittgenstein as well. Moreover, as the common cliché goes, the line between genius and madness is not always clear. Wittgenstein, then, had good reasons to fear he would be treated as a madman. He also knew treating the madman with a 'common sense' attitude is offensive. Still, this is the approach he subscribes in OC. One could protest that what Wittgenstein prescribes is Therapy, ${ }^{44}$ which presumably implies a nonviolent approach, but if anything, Foucault's Histoire de la folie shows us how violent issuing therapy actually is.

\footnotetext{
${ }^{39}$ Histoire de la folie, xxviii.

${ }^{40}$ Quoted in Louis Sass, The Paradoxes of Delusion: Wittgenstein, Schreber, and the Schizophrenic Mind (1994), ix. (from Recollections of Wittgenstein).

${ }^{41}$ Quoted in Ibid., 74.

${ }^{42}$ Sass also describes Wittgenstein's personality as schizoid, though not necessarily in a pathological sense. See Louis Sass, "Deep Disquietudes: Reflections on Wittgenstein as Antiphilosopher", in Wittgenstein Biography and Philosophy, ed. James C. Klagge (2001), 98-155; Louis Sass, "Some Reflections on the (Analytic) Philosophical Approach to Delusion”, Philosophy, Psychiatry, \& Psychology 11:1 (2004), 71-80.

${ }^{43}$ Sass, The Paradoxes of Delusion, 101.

${ }^{44} \mathrm{Cf}$. fn. 19 above.
} 


\section{Abbreviations}
Histoire de la folie Foucault, Michel, Folie et déraison: Histoire de la folie à l'âge classique (Libraire Plon, 1961).
https://doi.org/10.14375/np.9782070295821
English trans.: History of Madness, eds. Jonathan Murphy and Jean Khalfa. London/New-York: Routledge, 2006. https://doi.org/10.4324\%2F9780203642603

$\mathrm{OC}$

Wittgenstein, Ludwig, On certainty: material from the last year and a half of Wittgenstein's life (1949-51), eds. G.E.M. Anscombe and G.H. von Wright, trans. G.E.M. Anscombe and Denis Paul. New York: Harper, 1969.

PI

Wittgenstein, Ludwig, Philosophical Investigations, trans. G.E.M. Anscombe [1953], 4th Edition. MA: Blackwell, 2009.

\section{References}

Baker, G.P. and Hacker, P.M.S., Wittgenstein: Rules, Grammar and Necessity, vol 2. Oxford, UK: Wiley-Blackwell, 2009.

\section{https://doi.org/10.1002/9781444315691}

Boyne, Roy, Foucault and Derrida: The Other Side of Reason. London/New-York: Routledge, 1990. https://doi.org/10.4324/9781315004129

Coliva, Annalisa, Moore and Wittgenstein, Skepticism, Certainty and Common Sense. London: Palgrave Macmillan, 2010.

https://doi.org/10.1057/9780230289697

De Pierris, Graciela, "Philosophical Scepticism in Wittgenstein's On Certainty," in: Scepticism in the History of Philosophy, ed. Richard H. Popkin, 181-196. Dordrecht: Springer, 1996. https://doi.org/10.1007/978-94-017-2942-0 13

Derrida, Jacque, Writing and Difference. London: Routledge, 2001.

https://doi.org/10.4324/9780203991787

Descartes, René, Meditations on First Philosophy [1641], trans. John Veitch [1901]. Reprinted in Descartes, René, Discourse on the Method and the Meditations. New York: Cosimo, 2008.

Gutting, Gary, "Foucault and the History of Madness," in The Cambridge Companion to Foucault, $2^{\text {nd }}$ edition, ed. Gary Gutting, 47-70. Cambridge: Cambridge University Press, 2005. https://doi.org/10.1017/cco19780521403320.004

Hacking, Ian, Foreword to Michel Foucault, History of Madness, eds. Jonathan Murphy and Jean Khalfa, ix-xii. London/New-York: Routledge, 2006. https://doi.org/10.4324\%2F9780203642603

Hamilton, Andy, Wittgenstein and On Certainty [Routledge Guidebook]. London: Rutledge, 2014.

https://doi.org/10.4324/9781315771762

Macherey, Pierre, "The Foucault-Derrida Debate on the Argument Concerning Madness and Dreams" in Foucault/Derrida: Fifty Years Later, eds. Olivia Custer, Penelope Deutscher and Samir Haddad, 3-20. Columbia Uni. Press, 2016.

https://doi.org/10.7312/columbia/9780231171953.003.0001 
G. E. Moore, "Proof of an External World" [1939], reprinted in G.E. Moore, Selected Writings, ed. Thomas Baldwin [1993], 147-170. London: Routledge, 2013. https://doi.org/10.4324/9780203769812

Sass, Louis A., "Some Reflections on the (Analytic) Philosophical Approach to Delusion," Philosophy, Psychiatry, \& Psychology 11:1 (2004), 71-80. https://doi.org/10.1353/ppp.2004.0047

"Deep Disquietudes: Reflections on Wittgenstein as Antiphilosopher", in Wittgenstein Biography and Philosophy, ed. James C. Klagge, 98-155. Cambridge: Cambridge University Press, 2001. https://doi.org/10.1017/cbo9780511624797.005

The Paradoxes of Delusion: Wittgenstein, Schreber, and the Schizophrenic Mind. Itacha, NY: Cornell University Press, 1994.

Author info

Liat Lavi, PhD

Post Doc

Bezalel Academy for

Arts and Design

Jerusalem

Bar Ilan University

Ramat Gan 